\title{
Surgical and Protocolized Management of Distal Radius Nonunion
}

\section{Manejo quirúrgico y protocolizado de la pseudoartrosis de radio distal}

\author{
Juan María Pardo García ${ }^{1}$ Verónica Jiménez Díaz ${ }^{1}$ \\ Miguel Porras Moreno ${ }^{3}$ David Cecilia López ${ }^{1,2}$ \\ Service, Hospital Universitário Doce de Octubre Madrid, Spain \\ 2 Universidad Complutense de Madrid (UCM), Madrid, Spain \\ ${ }^{3}$ Hospital Villalba (Comunidad de Madrid), Madrid, Spain
}

Amaya Barberia Biurrun ${ }^{1}$ Lorena García Lamas ${ }^{1}$

Address for correspondence Juan María Pardo García, MD, Av. Córdoba s/n, 28041, Madrid (Comunidad de Madrid), Spain (e-mail: jmapgarci@gmail.com).

\section{Abstract \\ Keywords \\ - distal radius fracture \\ - volar plate \\ - complications \\ - nonunion \\ - arthrodesis \\ - wrist reconstructive surgery \\ - cirugía reconstructiva de muñeca}

Introduction Nonunion of the distal radius is an extremely rare and serious complication with unpredictable outcomes. The aim of the present study is to analyze the radiological and functional results after a protocolized surgical treatment.

Material and Methods A retrospective review of case series of patients with diagnosis of nonunion of the distal radius surgically treated from 2010 to 2016. The diagnosis of nonunion was made at 6 months without signs of consolidation. According to computed tomography (CT) scan images, we propose a classification of this complication as type I: no deformity or mild deformity, with subchondral metaphyseal bone stock beneath lunate facet greater than $10 \mathrm{~mm}$, with no degenerative changes at the distal radioulnar joint (DRUJ); type II: moderate deformity or degenerative changes in the DRUJ, distinguishing between IIA and IIB based on the subchondral metaphyseal bone stock; and type III: degenerative changes at the midcarpal joint. In all cases, a reconstructive technique consisting of volar locking plate osteosynthesis with autologous tailored iliac crest graft was performed, hence none of the cases were classified as type III.

Results In total, six cases were included. Mean follow-up: 58 months (range: 30-108 months). Consolidation was achieved in a mean period of 5 months (range: 3-9 months). Average active range of motion: flexion: $54^{\circ}$ (range: $10^{\circ}-80^{\circ}$ ); extension: $40^{\circ}$ (range: $10^{\circ}-$ $85^{\circ}$ ); supination: $82.5^{\circ}$ (range: $75^{\circ}-85^{\circ}$ ); pronation $80^{\circ}$ (range: $55-85^{\circ}$ ); radial deviation: $15^{\circ}$ (range: $5^{\circ}-20^{\circ}$ ); and ulnar deviation $15^{\circ}$ (range: $5-20^{\circ}$ ). Mean strength: $24.15 \mathrm{Kg}(6.9-$ $35 \mathrm{Kg}$ ). The average score on the Visual Analog Scale (VAS) at rest was of $0.6(0-2)$, and with movement, it was of $1.8(0-4)$. The mean postoperative score on the Disabilities of the Arm, Shoulder and Hand (DASH) questionnaire was of 18.48 (range: $0-50.8$ ). Average radial height: $9.65 \mathrm{~mm}$ (range: $7-12 \mathrm{~mm}$ ); average radial angulation: $17^{\circ}\left(10^{\circ}-20^{\circ}\right)$; volar tilt: $8.36^{\circ}$ (range: $0.2^{\circ}-21^{\circ}$ ); average ulnar variance: $1.52 \mathrm{~mm}$ (range: $0-3.5 \mathrm{~mm}$ ). Complications: persistent nonunion, superficial wound infection, acquired residual ulnar club hand deformity, radiocarpal arthritis, and midcarpal arthritis. Nevertheless, no salvage received

March 20, 2020

accepted

July 20,2020
DOI https://doi.org/

10.1055/s-0040-1718454. ISSN 1698-8396.
Copyright $\odot 2020$ Thieme Revinter

Publicações Ltda, Rio de Janeiro, Brazil
License terms

(c) (i) $\ominus$ (\$) 


\section{Resumen}

\section{Palabras clave}

- fractura de radio distal

- placa volar bloqueada

- complicaciones

- pseudoartrosis

- artrodesis techniques were needed or requested during the follow-up, with all patients in an active work situation or living an active life in complete normality.

Conclusions The protocolized surgical treatment of pseudoarthrosis of the the distal radius, based on our proposed classification, offers good functional outcomes in the long-term follow-up.

Introducción La pseudoartrosis de la extremidad distal del radio (PEDR) constituye una complicación extremadamente infrecuente y con resultados impredecibles. El objetivo del presente estudio es analizar los resultados funcionales y radiológicos tras tratamiento quirúrgico protocolizado.

Material y Métodos Estudio retrospectivo de serie de casos tratados quirúrgicamente entre 2010 y 2016. Diagnóstico de pseudoartrosis a los 6 meses sin señales de consolidación. Planteamos una clasificación diferenciando entre tipos I, IIA, IIB y III. Tipo I: casos sin deformidad o deformidad leve con stock óseo metafisario subcondral bajo faceta semilunar $>10 \mathrm{~mm}$, sin alteraciones asociadas en la articulación radiocubital distal (ARCD); tipo II: deformidad moderada y/o afectación en el nivel de la $A R C D$, diferenciando entre IIA y IIB, en función de stock óseo metafisario subcondral; y tipo III: asociación de cambios degenerativos en articulación mediocarpiana. En todos los casos se llevó a cabo una técnica reconstructiva de preservación articular.

Resultados Hubo un total de 6 casos con seguimiento medio de 58 meses (rango: 30-108 meses). La consolidación fue alcanzada con una media de 5 meses (rango: 3-9 meses). Balance articular activo (BAA) final: flexión de $54^{\circ}$ (rango: $10^{\circ}-80^{\circ}$ ), extensión de $40^{\circ}$ (rango: $10^{\circ}-85^{\circ}$ ), supinación de $82,5^{\circ}$ (rango: $75^{\circ}-85^{\circ}$ ), pronación de $80^{\circ}$ (rango: $55^{\circ}-85^{\circ}$ ), desviación radial de $15^{\circ}$ (rango: $5^{\circ}-20^{\circ}$ ), y desviación ulnar de $15^{\circ}$ (rango: $5^{\circ}-20^{\circ}$ ). Fuerza media de $24,15 \mathrm{Kg}$ (rango: 6,9-35 Kg). En reposo, la Escala Visual Analógica (EVA) era de 0,6 (rango: 0-2), y, con actividad, era de 1,8 (rango: 0-4). El puntaje postquirúrgico en el cuestionario Disabilities of the Arm, Shoulder and Hand (DASH) fue de 18,48 (rango: 0-50,8). Altura radial: 9,65 mm (rango: 7-12 mm); angulación radial: $17^{\circ}$ (rango: $10^{\circ}-20^{\circ}$ ); inclinación volar: $8,36^{\circ}$ (rango: $0,2^{\circ}-21^{\circ}$ ); varianza ulnar: $1,52 \mathrm{~mm}$ (rango: $0-3,5 \mathrm{~mm}$ ). Complicaciones: pseudoartrosis persistente, infección superficial, deformidad residual adquirida tipo mano zamba ulnar, artrosis radiocarpiana, y artrosis mediocarpiana. Ninguno de los casos precisó artrodesis como técnica de rescate, encontrándose todos en situación laboral activa o realizando una vida activa con total normalidad.

Conclusiones El tratamiento quirúrgico protocolizado, precoz y planificado basado en la clasificación propuesta por nosotros ofrece unos buenos resultados funcionales en el largo plazo sin precisar en ningún caso artrodesis como técnica de rescate.

\section{Introduction}

Complications after presenting a fracture of the distal end of the radius (DER) are frequent. Among these is nonunion of the distal end of the radius, which is defined as absence of consolidation after 6 months, ${ }^{1-3}$ and is an extremely rare and serious complication. Its low incidence, heterogeneity in the presentation of the cases, and the absence of a well-defined surgical algorithm are factors that make the results of its treatment unpredictable. ${ }^{4-6}$

Based on this, we review our experience in the treatment of this rare complication to analyze the functional and radiological results after a protocolized surgical treatment.

\section{Material and Methods}

We performed a retrospective study of a series of cases of patients with a diagnosis of nonunion of the distal radius treated surgically in our center between 2010 and 2016. A total of 7 patients were identified, and, in February 2019, we proceeded to the clinical review of 6 of these cases because of a loss in follow-up due to death related to the patient's medical comorbidities (chronic liver disease and dilated cardiomyopathy secondary to chronic alcoholism).

In all cases, the diagnosis of nonunion was established 6 months after the injury occurred, with the absence of bone bridging on computed axial tomography (CT). 
Table 1 Classification of nonunion of the distal radius

\begin{tabular}{|c|l|l|}
\hline Type I & & $\begin{array}{l}\text { No deformity or slight deformity. Metaphyseal bone stock under the lunate facet longer than 10mm. } \\
\text { No degenerative changes at the level of the DRUJ. }\end{array}$ \\
\hline Type II & A & $\begin{array}{l}\text { Degenerative changes in the DRUJ and/or } \\
\text { mild, moderate-severe deformity, with metaphyseal bone stock under the lunate facet longer } \\
\text { than } 10 \mathrm{~mm} .\end{array}$ \\
\cline { 2 - 3 } & B & $\begin{array}{l}\text { Degenerative changes in the DRUJ and/or } \\
\text { moderate-severe deformity with metaphyseal bone stock under the lunate facet shorter than } 10 \text { mm. }\end{array}$ \\
\hline Type III & & Degenerative changes in the midcarpal joint. \\
\hline
\end{tabular}

Abbreviation: DRUJ, distal radio ulnar joint.

Once diagnosed, given the heterogeneity in the presentation of this complication, we developed the following classification for descriptive purposes and in view of surgical planning: type I - cases without deformity or mild deformity with subchondral metaphyseal bone stock under the lunate facet longer than $10 \mathrm{~mm}$, without associated degenerative changes at the level of the distal radioulnar joint (DRUJ) (Figure 1). Type II: mild, moderate or severe deformity and/or degenerative changes at the level of the DRUJ, differentiating between IIA (Figure 2) and IIB based on the presence of bone stock under the lunate facet longer or shorter than $10 \mathrm{~mm}$ (Figure 3). Type III: cases with degenerative changes at the level of the midcarpal joint (Figure 4). A summary of the proposed classification is provided in - Table 1.

Data on personal history, comorbidities, and drug use were collected to identify possible risk factors, as well as the mechanism of the injury, the affected side, the initial treatment, and the complications (-Table 2 ).

In total, 2 women and 4 men were identified, and they had a mean age of 41 years (range: 35-62 years); the most affected side was the left in 4 cases, with 2 cases on the rightside; the right hand was the dominant hand in every case, all of the patients performed manual labor, and 3 of them performed hard manual labor. The most frequent pattern was a complex joint pattern after high-energy trauma in 4 of the 6 cases (cases 2, 3, 4 and 6), with grade IIIB open fractures in 2 (cases 2 and 4 ). Only one of the cases required a new intervention prior to referral to our center (case 3 ) due to delayed union and suspected infection consisting of: extraction of osteosynthesis material (EOM) and new synthesis with a volar plate and contribution of an autologous tricortical iliac crest graft. The mean time until the referral to our service was of 30 months (range: 6-120 months).

Average preoperative active range of motion: $34^{\circ}$ of flexion (range: $10^{\circ}-50^{\circ}$ ), $25^{\circ}$ of extension (range: $10^{\circ}-60^{\circ}$ ), $62.5^{\circ}$ of supination (range: $45^{\circ}-85^{\circ}$ ), $60^{\circ}$ of pronation (range: $30^{\circ}-85^{\circ}$ ), $5^{\circ}$ of radial deviation (range: $0^{\circ}-20^{\circ}$ ), and $8^{\circ}$ of ulnar deviation (range: $0^{\circ}-20^{\circ}$ ). The mean preoperative score on the Disabilities of the Arm, Shoulder and Hand (DASH) was of 49.1 (range: $38.6-60$ ).

Once each patient had been assessed in our unit, we proceeded to the early surgical intervention, after the preoperative planning with imaging tests (CT), evaluating the radial deformity, the metaphyseal bone stock under the lunate facet, the distal radioulnar joint, and the midcarpal joint. Based on this, the patients were divided according to the proposed classification system into: type I (case 1), IIA (cases 2,3,5 and 6), and IIB (case 4), and in every case we chose a joint preservation reconstruction technique. The type of surgical treatment is shown in - Table 2.

In every case, the Henry volar approach was performed, and samples were collected to rule out infection. The type of graft used was autologous from the iliac crest that was contralateral to the affected side, spongy for type I (case 1) and IIA with mild deformity and associated DRUJ involvement (case 2), and tricortical in those cases with moderate deformity (IIA), severe and/or bone stock under the lunate facet shorter than $10 \mathrm{~mm}$ (type IIB); the grafts were cut in relation to the defect, the deformity, and the intraoperative findings.

The use of external fixation (cases 3 and 5) as a complementary tool to the treatment for a period between 2 and 4 weeks to facilitate ligamentotaxis, and as supplementation to osteosynthesis and correction of the deformity obtained, was carried out in a patient with poor-quality bone (case 5) and in case 3 , the only patient reoperated before referral to our center due to delayed union and suspected subclinical infection. In both cases, the decision was made intraoperatively after the osteosynthesis, the correction of the deformity and the treatment of the DRUJ.

In every case except those with external fixation, immobilization with a dorsal forebrachial splint was carried out for a period of one week until the clinical review, and then we started to perform an early rehabilitation to increase joint mobility.

In the clinical review in February 2019, we performed: radiological control to analyze alignment parameters and detect new complications; a functional assessment through the measurement of active joint mobility; the return of the partients to their previous occupations; the measurement of the pain at rest and with movement through the Visual Analog Scale (VAS); the measurement of the strength with a manual dynamometer; and the application of the DASH questionnaire for the functional assessment of the entire upper extremity.

\section{Results}

In total, there were 6 cases of nonunion with a mean followup of 58 months (range: 30-108 months). The functional results are shown in - Table 2.

During the immediate postoperative period, 3 acute complications were identified: a case of hypoesthesia of the 


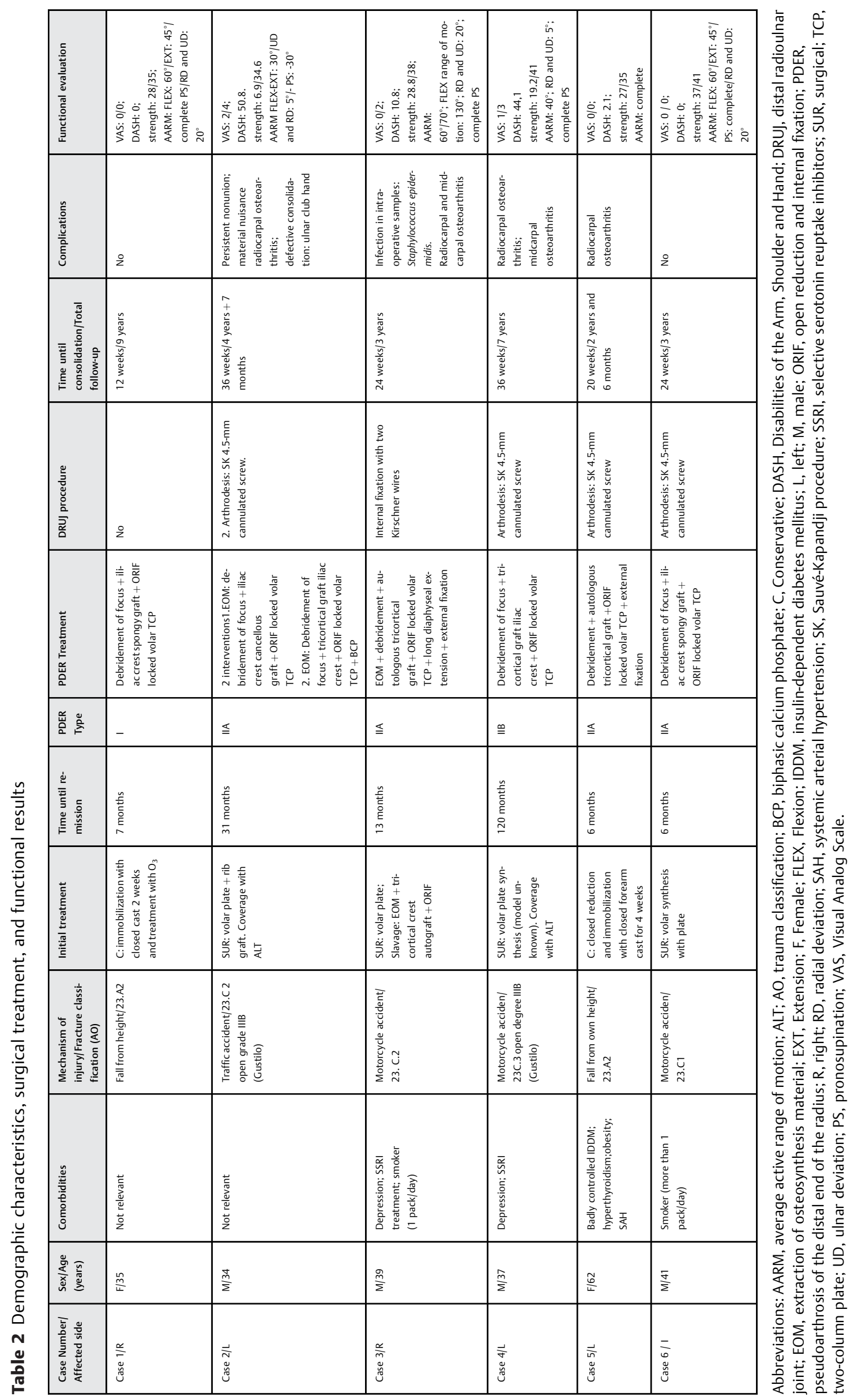




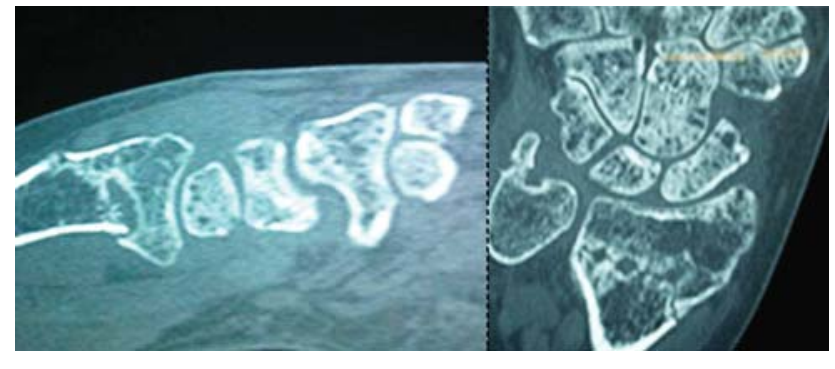

Figure 1 (color): Computed tomography (CT) scan of a patient with type I nonunion of the distal radius. Note the mild deformity, the bone stock larger than $10 \mathrm{~mm}$, and the absence of degenerative changes at the level of the distal radioulnar joint (DRUJ).

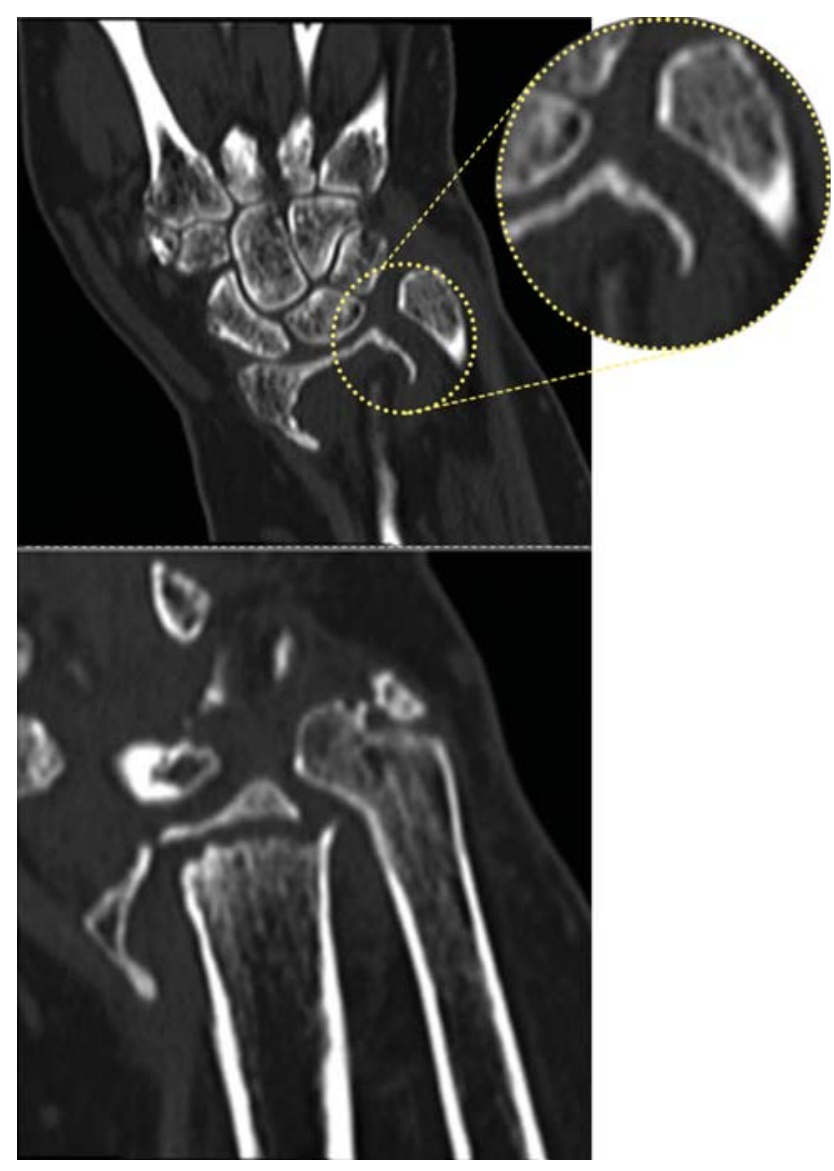

Figure 3 (color): Computed tomography image of a patient with type IIB. Note the absence of bone stock under the lunate facet and the changes at the level of the DRUJ, ulnar plus in relation to moderate radial deformity. No degenerative midcarpal changes.

sensory branch of the radial nerve (case 5) that did not require treatment, with spontaneous resolution 10 weeks after surgery, and a case of superficial infection (case 3) with an identified germ: Staphylococcus epidermidis, which was treated favorably with oral antibiotic therapy for a period of 4 weeks. In the rest of the cases, the results of the microbiology samples collected during the surgical procedure were sterile.

In all patients except one (case 2), healing of the fracture was achieved with a mean period of 5 months (range: 3-9 months). Case 2 constitutes the third complication: a persis-

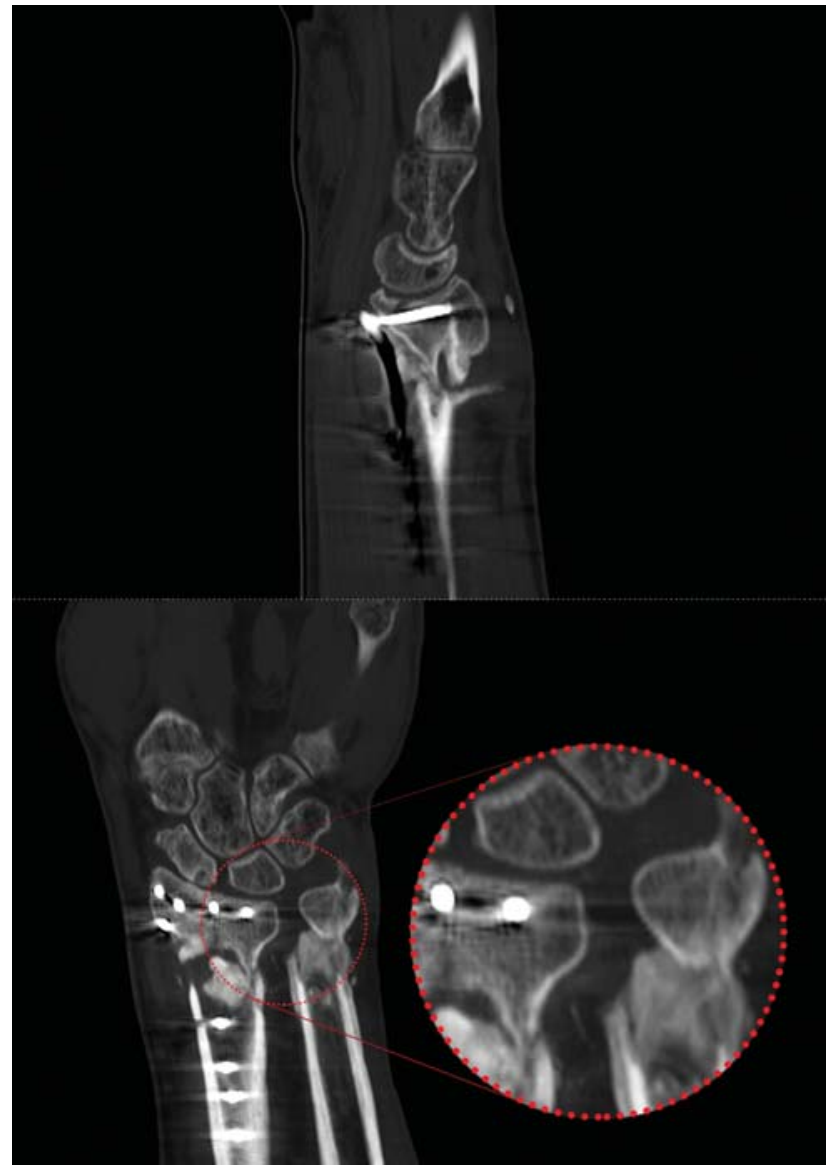

Figure 2 (color): sagital and coronal sections of a patient with type IIA. Observe the alterations at the level of the DRUJ with the subchondral metaphyseal bone stock under the lunate facet larger than $10 \mathrm{~mm}$ and moderate deformity.

tent nonunion that required surgical reoperation. We considered the subclinical infection with negative cultures as a possible etiology of the failure of the initial treatment, given the history of open grade IIIB fracture. To treat this complication, we chose a surgical treatment similar to the previous one, but more aggressive, consisting of extraction of osteosynthesis material, debridement with removal of devitalized bone tissue, autologous tricortical iliac crest graft with deformity correction and internal fixation with a volar two-column plate (TCP; DePuySynthes, Rayham, MA, US), in this case also adding a biphasic calcium phosphate (BCP) bone substitute, reserving the vascularized graft as a possible salvage option in case of persistent failure. In addition, a procedure was added at the level of the DRUJ (arthrodesis with the Sauvé-Kapandji technique) due to the progression of the deformity and the appearance of degenerative changes at that level. After the intervention, the cultures were sterile, and consolidation was achieved at 7 months without complications in the immediate postoperative period.

As complications in the medium term, the patient in case 2 presented discomfort related to the synthetis material, and proceeded to its extraction 3 years after the consolidation.

During the final check-up, the patients had an average active flexion joint mobility of $54^{\circ}$ (range: $10^{\circ}-80^{\circ}$ ), extension of $40^{\circ}$ (range: $10^{\circ}-85^{\circ}$ ), supination of $82.5^{\circ}$ (range: $75^{\circ}-$ 


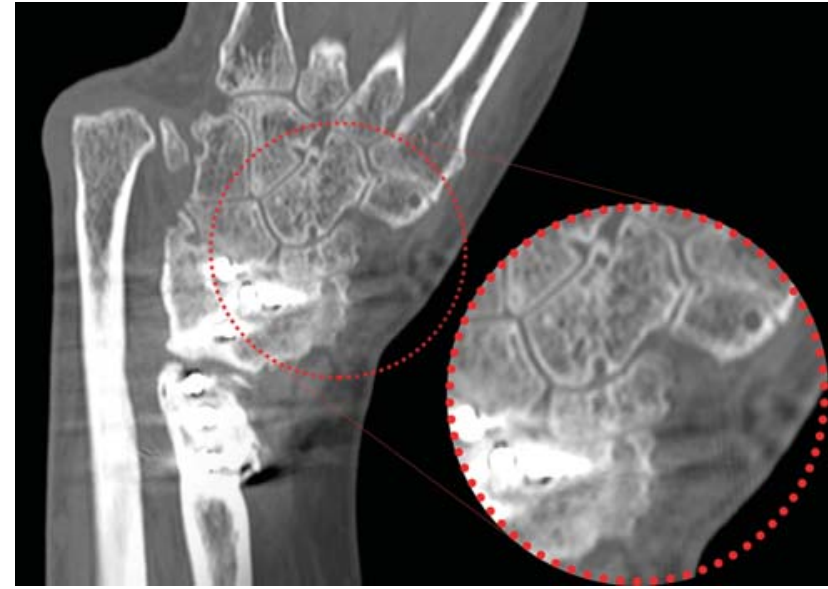

Figure 4 (color): Coronal CT image of a patient with type III Nonunion of the distal radius. Observe the associated degenerative changes at the level of the midcarpal joint. In these cases, we should consider arthrodesis as the initial treatment instead of reconstructive techniques.

$85^{\circ}$ ), pronation of $80^{\circ}$ (range: $55^{\circ}-85^{\circ}$ ), radial deviation of $15^{\circ}$ (range: $5^{\circ}-20^{\circ}$ ), and ulnar deviation of $15^{\circ}$ (range: $5^{\circ}-$ $20^{\circ}$ ). The average strength was of $24.15 \mathrm{Kg}$ (range: 6,9-35 $\mathrm{Kg}$ ), and it was only lower than $50 \%$ of the strength of the contralateral limb in cases 2 and 4 , who are the only patients who, even having returned to work, had to change their occupation as they were hard manual workers. It is also in these cases that we observed an active flexion-extension range of motion of about $20^{\circ}$, that is, lower than $50^{\circ}$, therefore, suboptimal, which, in the follow up, were associated with arthritic changes at the level of the radiocarpal and midcarpal joints. This may be because these patients presented, as a complication, grade IIIB open complex joint fractures with multiple interventions prior to the evaluation by our unit. However, given the current clinical situation (no pain at rest and little pain with movement) and the multiple previous surgical interventions, both patients rejected arthrodesis as a salvage technique and considered their mobility acceptable.

The average score on the VAS at rest was of 0.6 (range: $0-2$ ), and with movement, it was of 1.8 (range: $0-4$ ); The mean postsurgical score on the DASH was of 18.48 (range: 0-50.8).

Radiographic alignment parameters: mean radial height: $9.65 \mathrm{~mm}$ (range: $7-12 \mathrm{~mm}$ ); mean radial angulation: $17^{\circ}$ (range: $10^{\circ}-20^{\circ}$ ); mean volar tilt: $8.36^{\circ}$ (range: $0.2-21^{\circ}$ ); and mean ulnar variance: $1.52 \mathrm{~mm}$ (range: $0-3.5 \mathrm{~mm}$ ). Through the radiological analysis with a mean follow-up of 58 months, we detected long-term complications: 1 case acquired deformity, a defective consolidation of the ulnar club hand type (Figure 5), 4 cases of radiocarpal osteoarthritis (cases 2, 3, 4 and 5), and 3 at the midcarpal level (cases 2, 3 and 4). However, no patient required new surgical interventions or salvage techniques such as arthrodesis ,since they were satisfied with the results and practically without pain at rest, with mild pain with movement, all of them actively working or living a normal life without limitations.

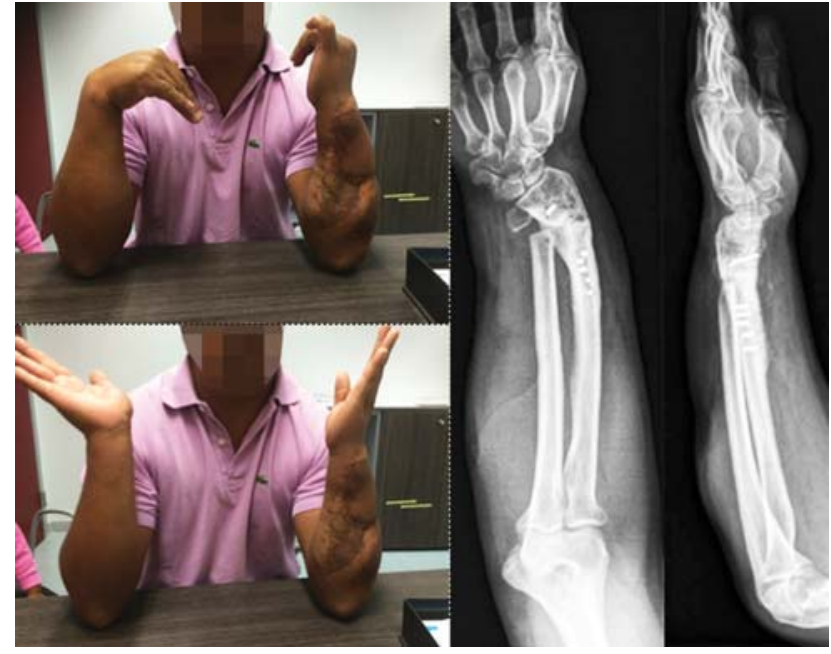

Figure 5 (color): Images corresponding to case number 2, with a score on the Disabilities of the Arm, Shoulder and Hand (DASH) at the end of follow-up of 50.8. The patient was submitted after multiple previous surgical interventions, had a persistent nonunion, and underwent a subsequent extraction of osteosynthetis material. Note the acquired residual ulnar club hand deformity at the end of the follow-up, after consolidation has been achieved. However, the patient refused surgery to correct the deformity.

\section{Discussion and Conclusions}

Nonunion of the distal radius is a rare and infrequent complication.

In a study involving more than 2000 distal radius fractures, Bacorn and Kurtzke ${ }^{7}$ described an incidence of nonunion of $0.2 \%$. In turn, Watson-Jones ${ }^{8}$ describes a single case out of a total of 3,199 fractures of the distal end of the radius. In addition, Bentohami et $\mathrm{al}^{9}$ did not register this complication after performing a systematic review of the complications in DER fractures treated with a locked volar plate. Among other factors, this is due to the important intraosseous vascularization at this level from three systems: the epiphyseal, metaphyseal and diaphyseal systems, at the volar and dorsal levels, as described in the anatomical study published in 2008 by Lamas et a ${ }^{10}$ However, the risk factors inherent to the fracture, such as high comminution, associated distal ulnar fracture, high-energy trauma or open fractures, as well as the risk factors of the patient (uncontrolled diabetes mellitus, significant smoking, peripheral vascular disease, alcoholism, hypothyroidism, and morbid obesity), have been described as associated with this complication $^{1-4}$. Osteoporosis does not seem to be a possible associated independent risk factor, as recent studies have analyzed. ${ }^{11}$ Moreover, inadequate treatment such as an insufficient immobilization period, excessive distraction of the fracture site, or the presence of a bone gap at the level of the metaphyseal region after the surgical treatment of distal radius fractures have also been related to an increase in this complication. ${ }^{1-3}$ The possibility of an increase in its incidence has been associated with the increase in the number of cases treated surgically with volar plate synthesis with locked screws. However, there does not appear to be a 
correlation with the onset of this complication and the use of state-of-the-art locked volar plates.

In the present study, we decided to define the time for diagnosis of distal radius nonunion according to the absence of signs of consolidation six months after the fracture. ${ }^{12,13}$ However, the absence of signs of consolidation 4 months after the fracture after following the adequate treatment should make us suspect of this condition and alert us to the need to carry out an imminent early surgical treatment, as mentioned in the study by Fernandez et al. ${ }^{3}$ In the present study, this was not possible since all of the cases except for one (case 5) were referred to our unit from other centers, where they were treated with a mean period of 30 months until remission.

Regarding the surgical treatment of nonunion of the distal radius, the traditional criteria that has been followed in the rest of the publications in the literature for the choice of joint preservation techniques or wrist arthrodesis was that established by Segalman and Clark ${ }^{1}$ in 1998, in a series of 12 cases, 8 of which were treated surgically. The authors established that the metaphyseal bone stock under the lunate facet shorter than $5 \mathrm{~mm}$ would lead to the need to perform an arthrodesis; on the other hand if it is longer than $12 \mathrm{~mm}$, this would enable the performance of a reconstructive technique of joint preservation. In our case, we decided to define the bone stock as $10 \mathrm{~mm}$, as this is a simpler value at the time of preoperative planning as well as a sufficient bone stock that enables us to perform a synthesis with a volar plate locked in the correct position without conditioning a more distal presentation of the plate associated with a greater number of complications, such as rupture and tendon irritation of the flexor pollicis longus. Following what was mentioned in the case series described by Fernandez et $\mathrm{al}^{3}{ }^{3}$ we agree that the conservative management of this disease should be reserved only in cases of patients with low functional demand or high associated comorbidities. In these cases, the treatment would consist of periodic immobilization of the joint coinciding with the episodes of exacerbation of pain. In addition, we agree to always try to perform reconstructive joint preservation techniques regardless of the bone stock under the lunate facet if we make a prior assessment of the midcarpal joint and it is intact. Otherwise, in these cases, which generally present in the form of severe deformity and decreased bone stock, arthrodesis should be considered as the first option for the surgical treatment.

Following these criteria, we achieved consolidation with good functional results in all patients in our series, with only one case of persistent nonunion that required a new surgical intervention, possibly as a result of a subclinical infection. We prefer to perform a procedure without the supply of vascularized bone graft, reserving it as a possible salvage technique and based on other cases of persistent pseudoarthrosis treated in this way with good results, such as cases 2 and 3. However, vascularized bone graft should be considered as an option in the case of persistent nonunion and even as the first possibility of treatment of nonunion of the distal radius. ${ }^{14-16}$

From the point of view of the radiological analysis, we consider the results acceptable, given the severity of this complication and the follow-up period. In the case of the positive mean ulnar variance obtained of $1.52 \mathrm{~mm}$ (range: 0 $3.5 \mathrm{~mm}$ ), it can be attributed to several factors that must be taken into account.

Firstly, the collapse of the radial height together with the increase in the depth of the joint cavity as a consequence of the secondary osteoarthritis developed can originate an associated ulnar plus, as occurs in the case with greater ulnar variance (case 3: $3.5 \mathrm{~mm}$ ). In addition, an insufficient procedure associated with the DRUJ may be insufficient, such as the one we think may have happened in case 3 , whose fixation was performed with Kischner wires (KWs). For this reason, we consider it crucial to not underestimate the assessment of this joint together with the treatment of nonunion of the distal radius to avoid associated long-term complications. However, the patient in case 3 is free of symptoms at the ulnocarpal level, despite the radiological findings.

The present study constitutes a series of six cases of an extremely rare complication; nevertheless, it is one of the most numerous in the international literature, which shows the heterogeneity in the presentation of the cases, although they can be divided according to the classification proposed, which we consider to be more reproducible, innovative, and with a contribution that is not only descriptive, but that also works as a guide in the decision-making process regarding the type of surgical treatment.

In addition, the total mean follow-up of 5 years, the longer being of 9 years, provides us with information on good and acceptable long-term functional results with the application of this algorithm without having to perform arthrodesis in any of the cases, even despite the development of arthritic changes and poor mobility, with an active flexion-extension arch lower than $50^{\circ}$, as in cases 2 and 4 .

However, the present is a retrospective study with the biases that this involves, where the number of cases is low, with the absence of a control group that would enable us to make comparisons regarding this type of treatment. New prospective studies, and, due to the low incidence of this complication, multicenter studies, are necessary to try to clarify which factors have the most influence on its onset, how to prevent it, and in case of its onset, establish which is the best method of surgical treatment.

\section{Conflict of Interests}

The authors have no conflict of interests to declare.

\section{References}

1 Segalman KA, Clark GL. Un-united fractures of the distal radius: a report of 12 cases. J Hand Surg Am 1998;23(05):914-919

2 Prommersberger K-J, Fernandez DL, Ring D, Jupiter JB, Lanz UB. Open reduction and internal fixation of un-united fractures of the distal radius: does the size of the distal fragment affect the result? Chir Main 2002;21(02):113-123

3 Fernandez DL, Ring D, Jupiter JB. Surgical management of delayed union and nonunion of distal radius fractures. J Hand Surg Am 2001;26(02):201-209

4 Harper WM, Jones JM. Non-union of Colles' fractures: Report of two cases. J Hand Surg Am 1990;15B:121-123 
86 Surgical and Protocolized Management of Distal Radius Nonunion Pardo et al.

5 Kwa S, Tonkin MA. Nonunion of a distal radial fracture in a healthy child. J Hand Surg [Br] 1997;22(02):175-177

6 McKee MD, Waddell JP, Yoo D, Richards RR. Nonunion of distal radial fractures associated with distal ulnar shaft fractures: a report of four cases. J Orthop Trauma 1997;11(01):49-53

7 Bacorn RW, Kurtzke JF. Colles' fracture; a study of two thousand cases from the New York State Workmen's Compensation Board. J Bone Joint Surg Am 1953;35-A(03):643-658

8 Watson-Jones R. Fractures and Other Bone and Joint Injuries. Edinburgh, Churchill Livingstone1942

9 Bentohami A, De Burlet K, De Korte N, Van den Bekerom MPJ, Goslings JC, Schep NWL. Complications following volar locking plate fixation for distal radial fractures: a systematic review. J Hand Surg Eur Vol 2013;0E(00):1-10

10 Lamas C, Llusà M, Méndez A, Proubasta I, Carrera A, Forcada P. Intraosseous vascularity of the distal radius: anatomy and clinical implications in distal radius fractures. Hand (N Y) 2009;4(04): 418-423
11 Gorter EA, Gerretsen BM, Krijnen P, Appelman-Dijkstra NM, Schipper IB. Does osteoporosis affect the healing of subcapital humerus and distal radius fractures? J Orthop 2020; 22:237-241

12 Hamada G. Extra-articular graft for non-union in Colles's fracture. J Bone Joint Surg 1944;26:833-835

13 Liverneaux P, Facca S, Hidalgo Diaz JJ. [Nonunion after distal radius fracture: A review]. Hand Surg Rehabil 2016;35S:S120-S125

14 Saremi H, Shahryar-Kamrani R, Ghane B, Yavarikia A. Treatment of Distal Radius Fracture Nonunion With Posterior Interosseous Bone Flap. Iran Red Crescent Med J 2016;18(07):e38884

15 Crow SA, Chen L, Lee JH, Rosenwasser MP. Vascularized bone grafting from the base of the second metacarpal for persistent distal radius nonunion: a case report. J Orthop Trauma 2005;19 (07):483-486

16 Kokmeyer D, Merrell GA, Kleinman W, Baltera RM. The use of a vascularized distal ulna autograft for complex distal radius fracture nonunions. J Hand Surg Am 2020;45(02):163.e1-163.e4 